Dossiê: Conferência de Puebla: 40 anos - Artigo original (a) (1)

\title{
Puebla 40 anos depois: a hora de retomar a tradição eclesial libertadora
}

\author{
Puebla 40 years later: \\ the time to resume the liberating ecclesial tradition
}

Agenor Brighenti*

\begin{abstract}
Resumo
A presente abordagem de Puebla 40 anos depois se propõe identificar as sincronias e diacronias entre o contexto de ontem e de hoje, postulando que o pontificado novo de Francisco é um momento oportuno para retomar a tradição eclesial libertadora, tecida sobretudo em torno a Medellín e Puebla. É uma abordagem marcadamente de cunho histórico, tendo como referenciais de análise a renovação do Vaticano II e sua recepção criativa por Medellín, que teve em Puebla um contraponto de segmentos conservadores e em Santo Domingo seu estancamento. O texto está estruturado em três partes: na primeira, faz referência ao consenso entre magistério e teologia latino-americana em Medellín, ao confronto em Puebla e Santo Domingo, hoje neutralizados por Francisco; na segunda parte, apresenta em grandes linhas o processo de "involução eclesial", iniciado a meados da década de 1980 e que se prolongou até Aparecida e a eleição do Papa Francisco; na terceira parte, dado o novo momento eclesial criado por Aparecida e o novo pontificado, justifica-se que há uma nova chance para a tradição eclesial libertadora. O texto aponta que hoje não se pode perder de vista a contribuição de Puebla, desqualificadora de posturas nostálgicas de um passado sem retorno e capaz de alentar a esperança renovada na tradição eclesial libertadora da Igreja na América Latina.
\end{abstract}

Palavras-chave: Puebla. América Latina. Vaticano II. Evangelização. Pobres.

\begin{abstract}
Puebla's present approach 40 years later aims to identify the synchrony and diachrony between the context of yesterday and today, postulating that Francisco's new pontificate is an opportune moment to resume the liberating ecclesial tradition, woven above all around Medellín and Puebla. It is a markedly historical approach, having as reference the analysis of the renewal of Vatican II and its creative reception by Medellin, which had in Puebla a counterpoint of conservative segments and in Santo Domingo its stagnation. The text is structured in three parts: in the first, it makes reference to the consensus between Latin American teaching and theology in Medellin, the confrontation in Puebla and Santo Domingo, now neutralized by Francisco; in the second part, it outlines the process of "ecclesial involution", which began in the mid-1980s and continued until Aparecida and the election of Pope Francis; in the third part, given the new ecclesial moment created by Aparecida and the new pontificate, it is justified that there is a new chance for the liberating ecclesial tradition. The text points out that today Puebla's contribution cannot be lost sight of, disqualifying nostalgic stances from a past without return and capable of encouraging renewed hope in the liberating ecclesial tradition of the Church in Latin America.
\end{abstract}

Keywords: Puebla. Latin America. Vatican II. Evangelization. Poor.

Artigo submetido em 14 de junho de 2019 e aprovado em 22 de dezembro de 2019.

${ }^{*}$ Doutor em Ciências teológicas e religiosas pela Université Catholique de Louvain, Bélgica. Professor Adjunto no PPGT da PUCPR. País de origem: Brasil. E-mail: agenor.brighenti@pucpr.br 


\section{Introdução}

A renovação do Vaticano II e sua "recepção criativa"1 (SOBRINO, 1985) na América Latina feita por Medellín, assim como a tessitura da subsequente tradição eclesial libertadora por ele inaugurada, não tem sido um processo linear e nem tarefa fácil (SCATENA, 2008). A reforma do Concílio, desde a primeira hora, teve o contraponto de segmentos atrelados à mentalidade de cristandade (ALBERIGO, 2006), que começou com o movimento protagonizado pelo tradicionalista Gabriel Lefebvre e seu cisma, e se prolongou numa espécie de "reforma da reforma" do Concílio, até à renúncia de Bento XVI. Sem exagero, esta poderia ser interpretada como o desfecho do esgotamento de um largo processo de restauração de um projeto de Igreja, marcadamente de neocristandade ${ }^{2}$. Por sua vez, a tradição eclesial libertadora inaugurada por Medellín, tecida em torno às comunidades eclesiais de base, a leitura popular da Bíblia, a opção pelos pobres, a pastoral social e ao testemunho dos "mártires das causas sociais", logo teve também a oposição de segmentos conservadores, articulados em torno ao Conselho Episcopal Latinoamericano (CELAM), com o apoio de segmentos da própria Cúria Romana. Prova disso, Puebla já seria um freio a Medellín e, Santo Domingo, praticamente seu estancamento.

Hoje, passados 40 anos de Puebla, por um lado, o Papa Francisco retoma o processo de recepção do Vaticano II e está empenhado em levar avante as reformas pendentes há mais de meio século, sobretudo no âmbito das estruturas da Igreja, a começar pela Cúria Romana e, por outro, a Conferência de Aparecida resgatou Medellín (GUTIÉRREZ, 2010), que Francisco, em grande medida, tal como Paulo

\footnotetext{
${ }^{1}$ O sentido do termo "recepção" para indicar o processo de acolhida, por exemplo, de um concílio, foi explicitado, já na primeira hora da implementação da renovação proposta pelo Vaticano II, especialmente por Y. Congar. Já a categoria "recepção criativa" é de Jon Sobrino, utilizada para indicar que a recepção do Vaticano II pela Igreja na América Latina, tal como está plasmada em Medellín, não se trata de "implantação", mas de encarnação e desdobramento de suas intuições básicas e eixos fundamentais, fazendo dele, mais um "ponto de partida" do que um mero "ponto de chegada" (CONGAR, 1972).

${ }^{2}$ A denominada "nova evangelização", categoria de Medellín e assumida pela Evangelii Nuntiandi, de Paulo VI, referia-se à necessidade de uma profunda mudança na ação evangelizadora da Igreja, para poder levar adiante a renovação do Vaticano II. Entretanto, a mesma categoria, a partir da metade da década de 1980 foi usada para levar a cabo uma evangelização centrípeta, que basicamente consiste, em uma postura marcadamente apologética e proselitista, em sair para fora da Igreja para trazer de volta os católicos afastados para dentro dela. Rompendo com uma Igreja autorreferencial, modelo típico da neocristandade, o Papa Francisco tem contraposto uma "Igreja em saída", uma missão centrífuga, coerente com a perspectiva conciliar e o modo como a tradição eclesial latino-americana a recebeu.
} 
VI havia feito com Evangelii Nuntinadi, o universaliza com a Evangelii Gaudium, criando as condições para retomar o processo da tradição eclesial libertadora. Entretanto, ainda que a Igreja em âmbito universal viva um momento primaveril pela retomada do processo de renovação do Vaticano II e que a Igreja na América Latina se veja confirmada em sua tradição libertadora, em especial com a canonização de Dom Oscar Romero, tal como no contexto sócio-eclesial de Puebla, hoje, não são poucos os obstáculos na retomada do processo, outrora senão desautorizado e interrompido, pelo menos dificultado (BRIGHENTI, 2019, p. 204205). Os entraves vêm de dentro e de fora. De dentro da Igreja, frente ao atual pontificado apresenta-se a ousadia de segmentos eclesiais, que vão de seminaristas a cardeais, inclusive da Cúria Romana, bem como de organismos de Igreja de corte tradicionalista, de se contraporem a toda iniciativa de retomada do Concílio. A mesma reação e dos mesmos atores é manifestada diante de todo esforço de retomada das sendas abertas por Medellín e Puebla, mesmo que recentemente tenham sido resgatadas por Aparecida. De fora da Igreja, a ascensão de governos ideologicamente de direita, ultraliberais na economia e moralistas nos costumes, potenciam a militância de atores autodenominados de direita, atuantes sobretudo nas redes sociais, que rotulam todo compromisso cristão com o social e a promoção dos pobres e excluídos como ideologia de esquerda, alinhada ao comunismo, tal como ocorreu nos tempos das ditaduras militares, alicerçadas na ideologia de segurança nacional.

Seja como for, para a Igreja renovada do Vaticano II e comprometida com a opção pelos pobres da tradição eclesial libertadora, é hora de avançar. Para isso, o Concílio deu o rumo e Medellín propôs caminhos, que se Puebla não pôde avançar em seu tempo, hoje, o momento eclesial primaveril criado por Aparecida e o pontificado de Francisco, se apresenta como um imperativo para retomar o processo estancado. As proposições de Puebla, que Medellín reafirmou, continuam sendo um referencial inspirador, que como foi ponte para Aparecida, que resgatou o Vaticano II e a tradição eclesial libertadora, pode também ser caminho para nós hoje retomarmos ideais, zelosamente guardados durante o longo "inverno eclesial", que hora parece suplantado por promissora primavera. 


\section{Do fecundo consenso a confrontos hoje neutralizados por Francisco}

Medellín, tal como o Concílio Vaticano II, foi um daqueles raros momentos na história da Igreja, em que "magistério e teologia coincidiram" - J. Comblin (CONGAR, 1980, p. 11) ou convergiram. Mas, foi por pouco tempo, pois, Puebla já seria um freio a Medellín e, Santo Domingo, praticamente seu estancamento (PASSOS, 2019, p. 163). Com exceção da década de 1970, período de grande dinamismo e criatividade em torno às intuições de Medellín, até à Conferência de Aparecida realizada três décadas depois (2007), a "Igreja da libertação" sobreviveu graças a muita resistência e generosa resiliência, como "brasas sob cinzas" (BOFF, 1986). Tanto que seu "rosto próprio", assim como sua "palavra própria", tiveram que ser gestados em pouco mais de dez anos, entre Medellín e Puebla, em meio a condições adversas, marcadas por debates e embates (PALÁCIO, 2000, p. 51-64). O rosto próprio da Igreja na América Latina foi tecido em torno à tradição libertadora de Medellín: as comunidades eclesiais de base, a leitura popular da Bíblia, a pastoral social, uma Igreja toda ela ministerial, a teologia da libertação e a memoria dos mártires das causas sociais. Já sua "palavra própria" vem da primeira teologia nascida na periferia - a teologia da libertação, diferente da única teologia do centro, tida como universal. Trata-se de "uma reflexão da práxis à luz da fé" (G. Gutiérrez), portanto, momento segundo (reflexão) sobre um momento primeiro (a práxis da fé), que são as práticas das comunidades eclesiais inseridas profeticamente na sociedade. Por ter sido a primeira, diferente, nascida na periferia, crítica em relação à Igreja e à sociedade, logo tornou-se uma teologiamártir. Os teólogos, gestores da nova teologia, estiveram presentes em Medellín e ofereceram uma contribuição decisiva aos bispos, seja no processo de preparação, seja na realização da Conferência e na recepção de suas conclusões, reunidas nos denominados "documentos" de Medellín. Mas, os teólogos da libertação já não estiveram no interior da Conferência de Puebla. Os que se opunham à "recepção criativa" do Vaticano II feita por Medellín, tinham consciência da importância e da influência da nova teologia para as comunidades eclesiais inseridas profeticamente na sociedade, que eles queriam neutralizar. 
Inicialmente, a Conferência de Puebla (1979) tinha sido convocada por Paulo VI para fazer a recepção da Exortação Evangelii Nuntiandi, publicada em 1975, tanto que o documento conclusivo da Segunda Conferência Geral dos Bispos se intitula - A evangelização no presente e no futuro da América Latina. Entretanto, a morte de Paulo VI e a eleição de João Paulo II deram à Conferência outro rumo, já sinalizado pelo novo papa no discurso de inaugural do evento: "a verdade sobre Jesus Cristo, a verdade sobre a Igreja e a verdade sobre o homem”. A Exortação Evangelii Nuntiandi ficaria na penumbra. Na realidade, a afirmação do primado da ortodoxia sobre a ortopraxis nada mais era do que a expressão de um processo já então em curso, arquitetado na Assembleia do CELAM realizada em 1972 em Sucre, (KELLER, 2017, p. 84; SCATENA, 2019, p. 56-59), a qual se propunha revisar Medellín e combater a perspectiva libertadora por ele inaugurada, ambos como uma interpretação equivocada do Vaticano II (HOUTART, 1975, p. 10-24). O pontificado do Papa polonês, a promoção de J. Ratzinger à Congregação para a Doutrina da Fé e a presença do Cardeal Ângelo Sodano na Secretaria de Estado, sustentados por um grupo de cardeais e bispos conservadores da América Latina tendo à frente o Cardeal Alfonso López Trujillo (KELLER, 2017, p. 84), foram os pilares de três décadas de "involução eclesial” (GONZÁLEZ FAUS, 1989, p. 67-84), só estancada com a renúncia de Bento XVI e a eleição do Papa Francisco, em 2013.

Coerentes com suas premissas, o fato é que para estes segmentos conservadores, a Exortação Evangelii Nuntiandi não podia ser a referência da Conferência de Puebla, pois eles sabiam muito bem que o documento de Paulo VI era a acolhida por parte do magistério pontifício, da "recepção criativa" do Vaticano II feita por Medellín. Categorias da Evangelii Nuntiandi como libertação, evangelização e promoção humana, CEBs, opção pelos pobres, pecado social e mudança estrutural, etc., expressões da tradição eclesial libertadora da Igreja na América Latina, que haviam ficado implícitas no Vaticano II (CHENU, 1977, p. 7379) e tinham sido explicitadas no Continente, estavam sendo assumidas pelo magistério pontifício e universalizadas. Para os que se contrapunham à tradição libertadora inaugurada por Medellín, Puebla teria que ser o momento da "volta à 
grande disciplina” (LIBANIO, 1984), já sinalizada por João Paulo I e que, de fato, seria implementada nos dois pontificados seguintes.

Neste contexto, a Conferência de Puebla só poderia ter sido tensa (SOUZA, 2019, p. 71-79). Tal como aconteceria em Santo Domingo e inclusive em Aparecida, teólogos e teólogas ligados à teologia da libertação foram excluídos da Conferência, o que não impediu, entretanto, que vários bispos os levassem para assessorá-los a partir de fora da assembleia. Trabalharam na clandestinidade, munindo os participantes da Assembleia da memória de Medellín, produzindo textos, refletindo extra muros com os bispos, para desconcerto e desconforto daqueles que os haviam impedido de integrar oficialmente o evento (DUSSEL, 1983, p. 70-78). Graças a eles e aos bispos determinados em caminhar pelas sendas abertas por Medellín, ainda que Puebla seja um contraponto à tradição libertadora, a Igreja na América Latina conseguiu reafirmar seu "rosto próprio" e sua "palavra própria” (KELLER, 2017, p. 92).

A década pós-Puebla dos anos 1980, ainda que no âmbito sócio-político gradativamente se vai superar as ditaduras e reconstruir a democracia, no âmbito eclesial foram os anos mais difíceis para a tradição eclesial libertadora e sua reflexão teológica, marcados por suspeições e punições. Não somente os teólogos e teólogas, mas, sobretudo a "Igreja da libertação", praticamente teve que passar para a "clandestinidade eclesial", sem espaço de atuação e reconhecimento nas esferas oficiais. Infelizmente, a relação teologia-magistério passaria por um tempo marcado por gradativo distanciamento (FRANCO, 1984, p. 3). Viria a intervenção na Conferência dos Religiosos para a América Latina (CLAR)3, as duas Instruções da Congregação para a Doutrina da Fé com reticências à teologia da libertação (LORSCHEIDER, 1984), processos e punições a teólogos e teólogas, a nomeação de bispos com um perfil crítico à tradição eclesial libertadora, a suspeição de ideologização das comunidades eclesiais de base, entre outros, que levaram os teólogos e teólogas latino-americanos a se sentirem órfão de Igreja, ainda que

\footnotetext{
${ }^{3}$ Em 1989, houve a intervenção na CLAR por parte da Congregação para os Religiosos, nomeando-se uma nova diretoria e tirando o direito dos religiosos elegerem sua própria diretoria por anos. Entre os atos arbitrários contra a CLAR é conhecido o aborto do Projeto Palavra e Vida da CLAR; conferir sobre o projeto: Mesters (1989).
} 
continuassem estreitamente engajados nela na base (OLIVEROS, 1990, p. 35-36). Na década pós-Santo Domingo dos anos 1990, a situação continuaria a mesma, levando praticamente ao estancamento de Medellín. Soma-se a isso, um certo triunfalismo de movimentos eclesiais e outros organismos de corte conservador, típicos da neocristandade.

Hoje, graças ao pontificado de Francisco, a teologia latino-americana volta a recobrar cidadania eclesial e não consta que algum dos inúmeros processos contra teólogos na América Latina e no mundo esteja em andamento. Apesar das dificuldades encontradas, a teologia latino-americana está viva, graças aos seus congressos, a uma abundante produção e a presença na assessoria aos processos eclesiais e sociais nas bases e nas periferias. Teólogos e teólogas desta corrente teológica voltam a ser chamados a colaborar em processos eclesiais e, no momento, estão muito empenhados a repercutir e a refletir sobre o magistério do Papa Francisco. São atores que se pode contar na retomada do processo de recepção da tradição eclesial libertadora, emanada de Medellín e Puebla, e pode dar valiosa contribuição. Evidente que estamos num novo contexto e também a teologia latinoamericana está se ressituando no novo momento e, portanto, se refundando, em especial no seio de movimentos como os ligados a processos de decolonização, que implica novas posturas linguagens e tematização desde as epistemologias do Sul (TAMAYO, 2017).

Entretanto, também a teologia latino-americana se ressente das três décadas de involução eclesial. Do ponto de vista eclesial, nossa teologia depende, de um lado, das práticas eclesiais em perspectiva transformadora e, de outro, da inserção do teólogo numa comunidade eclesial concreta. Do lado das práticas, uma teologia libertadora depende da autenticidade do modo de ser Igreja das comunidades eclesiais. Enquanto existir pobres e Evangelho, a perspectiva profética e transformadora da ação eclesial é condição para a autenticidade da própria Igreja (PALÁCIO, 200o, p. 51-64). Uma Igreja órfã de sociedade leva a uma teologia órfã dos pobres e, portanto, órfã do Evangelho, porquanto a opção pelos pobres radica na fé cristológica (BENTO XVI, DI, Aparecida). Por isso, inviabiliza a profecia da 
teologia, nos dias atuais: o deslocamento da militância para a mística na esfera da subjetividade individual; a crescente espiritualização da pastoral, em detrimento do compromisso social; o serviço aos pobres, estes assumidos como objetos de caridade e não sujeitos de uma sociedade justa e solidária, inclusiva de todos; enfim, uma Igreja cada vez mais voltada sobre si mesma, para suas questões internas, silenciosa e omissa diante de situações que clamam aos céus.

Do lado da interação do ministério teológico com as práticas eclesiais e sociais, em perspectiva libertadora, está em causa lugar do teólogo e da teologia na academia. Como a teologia é "momento segundo", a inteligência reflexa de um “momento primeiro" que são as práticas eclesiais, em perspectiva transformadora, o distanciamento do teólogo destas práticas inviabiliza não só a profecia da teologia como compromete sua própria autenticidade, pois deixaria de ser uma contribuição a uma ação eclesial antecipadora da presença do Reino escatológico na concretude da história. Uma teologia hermenêutica-contextualizada, não pode perder de vista seu verdadeiro lugar, que é a comunidade eclesial, inserida por contraste num contexto marcado pela exclusão, em seus diferentes matizes (BOFF, 1986, p. 27). De pouco serve uma academia na Igreja que se limite levar os cristãos a repetir memoristicamente uma teologia de manuais, fruto de uma reflexão amordaçada pelo medo da investigação ou da pesquisa. Por isso, não deixa de ser também preocupante o gradativo retorno da teologia aos espaços eclesiásticos, a preferência por cursos seminarísticos aos acadêmicos, a volta dos manuais e dos catecismos ou a tentação de uma teologia apologética.

\section{Entre o imperativo de avançar e a nostalgia de um passado sem retorno}

Por ocasião da realização da Conferência de Puebla, em meio a regimes autoritários e a posturas eclesiásticas restauracionistas da neocristandade, a Igreja na América Latina vinha de uma década de profundas transformações e efervescência eclesial, em torno à renovação do Concílio Vaticano II e às opções de Medellín (BRIGHENTI, 2005, p. 375-398). Em dez anos, segmentos importantes da Igreja no Continente, em grande medida, havia deixado para trás o regime de 
cristandade renovando a liturgia, levando a cabo uma evangelização libertadora, promovendo as CEBs como nova forma de ser Igreja, implementando a pastoral social frente ao tradicional assistencialismo, capacitando os agentes de pastoral na leitura popular da Bíblia e respaldando os processos eclesiais e sociais dos cristãos inseridos profeticamente na sociedade com a teologia da libertação (BRIGHENTI, 2019, p. 206). Enfim, brilhava o testemunho dos mártires das causas sociais, semente de novos cristãos engajados profeticamente na sociedade. Foi este novo rosto de Igreja que marcou presença no processo de preparação e na realização da Conferência de Puebla, ainda que suas conclusões tenham ficado aquém do esperado, pois, dolorosamente se constaria que o que havia sido consenso em Medellín, já não o era mais em Puebla (RICHARD, 1979). Puebla, a duras penas, conseguiu reafirmar Medellín, mas sua recepção seria seriamente prejudicada pela ascensão de segmentos eclesiais conservadores, senão coniventes, pelo menos silenciosos diante dos horrores das ditaduras militares, que povoavam $o$ continente.

A década de Puebla, de 1980, ainda que no âmbito sócio-político as ditaduras militares gradativamente iriam ficando para trás e a democracia pouco a pouco foi sendo restabelecida, no âmbito eclesial ganharia cada vez mais terreno, com o apoio de segmentos da hierarquia do Continente e da Cúria romana, projetos restauracionistas da neocristandade, através de movimentos eclesiais conservadores, tidos como "a nova primavera" da Igreja. A "nova evangelização", categoria criada por Medellín para indicar a exigência de uma nova maneira de ser e de agir da Igreja para poder levar adiante a renovação do Vaticano II, passa a ser utilizada para levar a cabo uma "reforma da reforma" do Vaticano II, que redundaria em uma Igreja autorreferencial. Era o contraponto deliberado ao movimento de renovação e efervescência eclesial então vigente depois do Vaticano II e de Medellín, caracterizado pelo refluxo de posturas de neocristandade, revisionistas do Vaticano II (GUTIÉRREZ, 1987, p. 228) e, na América Latina, de desconstrução de Medellín (PASSOS, 2017, p. 164-165). Segmentos recalcitrantes da velha Igreja pré-conciliar falavam de corrigir "interpretações errôneas", seja do Vaticano II, seja de Medellín, desautorizando reflexões e combatendo práticas 
(DUSSEL, 1983, p. 70-78). O mais curioso é que era um movimento do centro para a periferia, da Cúria Romana e do CELAM em direção à CLAR, às Conferências Episcopais Nacionais e às Igrejas Locais. Tendia-se a satanizar as CEBs e a teologia da libertação (CONGREGAÇÃO PARA A DOUTRINA DA FÉ, 1990, p. 1552-1553), assim como colocar sob suspeita de politização da fé o compromisso social dos cristãos e até mesmo o testemunho dos "mártires das causas sociais" (ANTONCICH, 1991, p. 123). No seio destes segmentos conservadores, tudo era visto como infiltração marxista, até a opção pelos pobres e a prática de bispos profetas, denominados "bispos vermelhos”.

A queda do "muro de Berlim" ao final da década de 1980, foi ocasião para estes segmentos que confundiam todo compromisso social e com os pobres com comunismo, para decretar a morte da teologia da libertação, o ocaso das comunidades eclesiais de base e para lançar um olhar de suspeição sobre os mártires das causas sociais, taxados de instrumentalizar a fé em prol de ideologias fracassadas. Estas atitudes, associadas à ascensão de governos neoliberais, que governaram durante toda a década de 1990, levou os pobres a se sentirem órfãos não só de Igreja, mas também de sociedade.

A partir de nosso presente, olhando para trás 40 anos depois, ao retomarmos o processo de recepção de Puebla, percebemos que o momento atual guarda diacronias e sincronias com o contexto da Terceira Conferência. Como diferenças entre os dois contextos, em Puebla, estavam chegando à cúpula da Igreja atores que iriam implantar um largo processo de involução eclesial em relação à renovação do Vaticano II e à tradição eclesial libertadora. Hoje, ao contrário, temos um papa reformador, que resgata o Vaticano II e a tradição eclesial latinoamericana. Lá tínhamos uma Igreja se desvencilhando da cristandade, aqui, uma Igreja em meio a uma profunda crise da modernidade. Já como sincronias entre o contexto de ontem e o contexto de hoje, tal como a Igreja que chegava a Puebla alvejada pelo sangue de seus mártires, a Igreja que chega a Aparecida e ao pontificado de Francisco vem também da "grande tribulação" de três décadas de "involução eclesial", vivendo um tempo novo e de graça, de resgate do Vaticano II e 
de Medellín. Volta-se a falar de pobres, de pastoral social, de CEBs, de movimentos populares, de teologia da libertação, de Igreja profética, Dom Romero da América é canonizado, cessa o olhar de suspeição e de punição por parte da Cúria Romana sobre teólogos e teólogas, ainda que seja um espírito e um esforço mais do Papa e do laicato do que do clero, em especial dos bispos. Poucos poderiam imaginar este novo cenário, depois de três décadas marcadas por uma "Igreja autorreferencial", clericalista e promotora de uma espiritualidade pouco eclesial e encarnada. Muito se falou e se escreveu nestes últimos tempos sobre "o renascer de uma esperança", que se julgava batalha perdida.

Também diferente ao tempo de Puebla, no momento atual, as posturas conservadoras e revisionistas da renovação conciliar e da tradição eclesial libertadora, já não vêm do centro da Igreja, mas de segmentos tradicionalistas ligados a movimentos, que se posicionam abertamente contra o Papa Francisco e o Vaticano II. No tempo de Puebla, a maioria avançava e a minoria retrocedia. Hoje, a grande maioria das forças da Igreja é conservadora e uma minoria, que resistiu bravamente nas três décadas de "involução eclesial", sintoniza com o movimento de resgate da renovação conciliar e da tradição eclesial libertadora. No tempo de Puebla, buscava-se superar o clericalismo, impulsionando uma Igreja sinodal e profética, a começar pelos seminários, onde justamente hoje reside o nicho mais conservador e de resistência ao Papa Francisco. Já semelhante com o contexto de Puebla, o contexto atual é igualmente marcado pelo refluxo não só de posturas de neocristandade como também de cristandade, tridentinas, tradicionalistas, fundamentalistas, tanto na religião como na política e na cultura. Apesar da bela surpresa de Aparecida (SCATENA, 2019, p. 60-61), se não fosse o Papa Francisco, Aparecida já teria desaparecido. O próprio Papa se vê rodeado de vozes nostálgicas de um passado sem retorno, em oposição aberta ao seu pontificado reformador, inclusive da parte de alguns membros da própria Cúria Romana. E o mais escandaloso é o silêncio da maioria dos bispos, talvez porque ainda nomeados segundo o perfil do processo de involução eclesial que reinou por três décadas, assim como a volta do clericalismo e o do tradicionalismo em grande parte dos seminários. Alguns movimentos de Igreja, com muito dinheiro e outrora com 
muito prestígio e poder, não hesitam em falar "de cima dos telhados" que é preciso “salvar a Igreja” (BRIGHENTI, 2019, p. 209), voltar ao fundamento, à ortodoxia, à sã doutrina, em resumo, é hora de voltar a tomar distância do mundo moderno e profano, que supostamente conspira contra a Igreja (LADRIÈRE; LUNEAU, 1987, p. 161-178). É neste contexto que o processo de recepção de Puebla é retomado, tarefa complexa, mas imprescindível para o futuro da Igreja e a Igreja do futuro.

\section{Retomar Puebla apoiados no momento favorável criado por Francisco}

O contexto de Puebla, caracterizado pela mobilização popular e pelas manifestações sociais na conquista do direito a participar da vida da sociedade, foi marcado também pelo autoritarismo, tanto interna como externamente à Igreja (KELLER, 2017, p. 84). Externamente, o contexto de Puebla era de uma sociedade subjugada por cruéis e sangrentas ditaduras militares, onde imperava a censura, a repressão, a criminalização dos movimentos sociais, a corrupção do Estado, acompanhada do aumento do desemprego e da brecha crescente entre ricos e pobres (COUTINHO, 2019, p. 85-91). Em contrapartida, havia intensa sede de participação por parte das classes populares e dos intelectuais, em vista da reconstrução da democracia (PASSOS, 2019, p. 159-160). Por sua vez, os regimes autoritários justificavam suas posturas antidemocráticas pela "ideologia de segurança nacional”, “defendo a civilização ocidental cristã”, frente ao perigo do comunismo (COMBLIN, 1978). Respaldados por esta ideologia, direitos são suprimidos, em especial os relativos à participação cidadã e a liberdade de expressão.

Internamente, a Igreja na América Latina estava engajada num franco processo de vivência e aprofundamento da sinodalidade eclesial (SCATENA, 2019, p. 51-53), desde as bases até no seio das Conferências de Bispos em âmbito continental, nacional e regional (DORTEL-CLAUDOT, 1973, p. 47-84). Em grande parte das Igrejas Locais, se elaboram planos de pastoral de conjunto de forma participativa, os âmbitos eclesiais se regem por assembleias e conselhos de pastoral e os serviços de pastoral são gestados por equipes de coordenação. Era costume 
envolver a comunidade eclesial, desde as comunidades de base, em processos de consulta, de elaboração de planos ou mesmo na preparação de grandes eventos como foi na ocasião a Conferência de Puebla, que contou com farta contribuição das Igrejas Locais. Em contrapartida, no âmbito da Cúria romana, a sinodalidade eclesial tocava o nível mais baixo de sua história, seja pela centralização e o enfraquecimento das Igrejas Locais (CONGAR, 1980, p. 130-144), seja pela intervenção nos estatutos das Conferências Nacionais de Bispos e nos seminários. A própria Conferência de Puebla teve explícito cerceamento da participação por parte de membros da Cúria romana e de segmentos do CELAM, não só de bispos como dos teólogos da perspectiva de Medellín, que tiveram que atuar clandestinamente, do lado de fora da assembleia (NERY, 2017, p. 399-411). A década de Puebla é um tempo marcado por controles e advertências, por processos contra teólogos e teólogas (FRANCO, 1984, p. 3), silêncios obsequiosos, zelo pela ortodoxia e pureza da doutrina, enfim, é o tempo das visitas ad limina a uma Cúria romana autoritária e censora. Impunha-se um novo perfil de clero, em especial de bispos, marcados pela distância da tradição eclesial libertadora, mais administradores que pastores. Apesar disso, sairia de Puebla uma Igreja decidida a levar adiante a herança de Medellín, apesar dos obstáculos internos e externos. Entre perseguição e morte, tomou-se consciência que "a libertação é um ideal não dos vencedores, mas dos vencidos; é resistência no exílio" (BOFF, 1986). E a tradição eclesial libertadora resistiu, inclusive ao momento crítico da Conferência de Santo Domingo, para ressurgir das cinzas em Aparecida e no pontificado de Francisco.

No momento atual, diacronicamente ao tempo de Puebla, já não há ditaduras militares e se respira ares de liberdade e de participação cidadã, fruto da conquista da democracia, embora frágil e manipulada pela burguesia. Entretanto, depois de algumas décadas de governos de corte popular, marcados pela promoção de políticas inclusão social, há ascensão de governos com posturas autoritárias e antissociais, que chegam ao poder seja por eleições manipuladas pela mídia seja através de golpes parlamentares, avalizados por um poder judiciário politizado. Diante da crise da democracia representativa, que representa os interesses da 
burguesia, se aposta em governos antidemocráticos, com posturas xenofóbicas e preconceituosas em relação a minorias, satanizadores das políticas de esquerda e autoconfessos de direita. Com o moralismo em torno ao combate à corrupção, aos valores da família, às "ideologias de esquerda”, em especial frente ao combate a um suposto perigo comunista, justificam o desrespeito à ordem jurídica e constitucional. Governos autoritários assumem um caráter populista, através de medidas aparentemente em favor do povo, quando na realidade respondem aos interesses do grande capital nacional e, sobretudo, internacional, em especial do sistema financeiro.

No âmbito eclesial, diferente do tempo de Puebla, hoje, a sinodalidade é mais uma insistência do Papa do que uma aspiração de instâncias outrora sinodais e hoje permeadas de clericalismo de clérigos e de leigos clericalizados. A larga experiência sinodal da Igreja na América Latina sobrevive como "brasas sob cinzas”, nos espaços de resistência e resiliência como são as comunidades eclesiais de base, frente à volta de uma "pastoral de conservação", centralizada no padre e na paróquia, em torno à recepção dos sacramentos e a práticas devocionais (BRIGHENTI, 2019, p. 210). Em nome de um suposto risco de invasão do comunismo, posturas fundamentalistas e tradicionalistas, com o apoio principalmente do pentecostalismo evangélico e católico, promovem e legitimam governos de direita, assim como desqualificam iniciativas da Igreja na perspectiva da renovação do Vaticano II e da tradição eclesial libertadora. Para isso, recorrem a métodos nada evangélicos, como o linchamento público nas redes sociais ou mesmo o método dos novos anticomunistas, o uso de fake news. Continuamos em tempos marcados por contratempos múltiplos, internos e externos à Igreja, mas, felizmente, fortalecidos com um pontificado novo e profético, reformador e determinado em levar adiante a renovação do Vaticano II e a tradição eclesial libertadora da Igreja na América Latina. Não podemos nos furtar dos ventos favoráveis que sopram, por este Papa, das Igrejas e dos povos do hemisfério Sul, em especial de nosso subcontinente. 


\section{Considerações finais}

É em meio a este contexto que, 40 anos depois de Puebla, estamos desafiados a retomar a tradição eclesial libertadora, que nasce em torno a Medellín. As dificuldades não são poucas, pois o contexto atual guarda características muito semelhantes com o tempo em que os atores da III Conferência trataram reafirmar a "recepção criativa" do Vaticano II no documento final e a consequente implementação em suas Igrejas Locais. Mas, há um diferencial significativo - o pontificado de Francisco, que não só avaliza com seu magistério a herança de Medellín confirmada por Puebla, como convoca a Igreja inteira a sair para as periferias, a ser uma Igreja samaritana e profética, tal como a Igreja na América Latina vem tentando fazer realidade em meio a obstáculos de toda ordem. Nas intuições de Medellín e Puebla, "a esperança dos pobres vive" (COMBLIN). E como a esperança cristã é uma esperança ativa, esperar é ir antecipando na concretude da história as aspirações dos pobres, os bem-aventurados de Deus. Cabe lembrar, entretanto, que como diz Aparecida, tem nos faltado "coragem, persistência e docilidade para continuar a renovação iniciada pelo Vaticano II e impulsionada pelas demais Conferências Gerais anteriores, em vista de um rosto latinoamericano e caribenho de nossa Igreja" ( $D A p$ 10oh). Prova disso, são "as tentativas de voltar a uma eclesiologia e espiritualidade contrárias à renovação do Vaticano II" (DAp 10ob).

Por isso, dado o prolongamento da "paixão de Jesus Cristo na paixão do mundo" (BOFF), não basta que as intuições de Medellín e Puebla estejam vigentes. É grave que elas continuem pendentes e, em grande medida, adormecidas, apesar do novo momento eclesial criado pelo pontificado de Francisco. É hora de retomar o caminho da tradição eclesial libertadora inaugurada por Medellín, reafirmada por Puebla e resgatada por Aparecida e avançar. No horizonte da libertação, está a liberdade, que nos liberta de todo medo e nos faz livres para libertar. 


\section{REFERÊNCIAS}

ALBERIGO, G. Breve storia del concilio Vaticano II (1959-1965). Bologna: Il Mulino, 2006.

AMERINDIA. Aparecida, renacer de uma esperanza. Bogotá: Indo-American Press, 2007.

ANTONCICH, R. El servicio intelectual a la verdad. Reflexiones en torno a la instrucción sobre la Vocación Eclesial del Teólogo. Medellín, Bogotá, n. 65, p. 113-129, 1991.

BOFF, L. Lectura del documento de Puebla desde América Latina oprimida. In: CARDEDAL, Olegario Gonzáles de; PEÑA, Juan Luis Ruiz de la; ESCUELA AUSTURIANA DE ESTUDIOS HISPÁNICOS. Puebla el hecho histórico y su significación teológica. Salamanca: Ed. Sígueme, 1981.

BOFF, L. Teología desde el lugar del pobre. Santander: Sal Terrae, 1986.

BRIGHENTI, A. El Pacto de las Catacumbas y la tradición eclesial liberadora. In: PIKAZA, X.; SILVA, José Antunes da (ed.). El Pacto de las Catacumbas: la misión de los pobres en la Iglesia. Navarra: Verbo Divino, 2015. p. 213-230.

BRIGHENTI, A. Conferências Gerais e questões disputadas: razões subjacentes a tensões e embates. In: BRIGHENTI, A.; PASSOS, J. D. (org.). Compêndio das conferências dos bispos da América Latina e Caribe. São Paulo: Paulinas: Paulus, 2017. p. 175-190.

BRIGHENTI, A. Énfasis pastorales de la Iglesia en América Latina y El Caribe en los últimos 50 años. Medellín, Bogotá, n. 123, p. 375-398, 2005.

BRIGHENTI, A. Tendências atuais e evangelização no futuro. In: SOUZA, N. de; SBARDELOTTI, E. (org.). Puebla: Igreja na América Latina e no Caribe. Opção pelos pobres, libertação e resistência. Petrópolis: Vozes, 2019. p. 204-220.

CHENU, M. D. La Iglesia de los pobres en el Vaticano I. Concilium, Petrópolis, n. 124, p. 73-79, 1977.

COMBLIN, J. A ideologia de segurança nacional: o poder militar na América Latina. Rio de Janeiro: Civilização Brasileira, 1978.

CONGAR, Y. Autonomie et pouvoir central dans l'Église vus par la théologie catholique. Irénikon, Chevetogne, v. 53, p. 291-313, 1980.

CONGAR, Y. La réception comme réalité ecclésiologique. Revue des Sciences Philosophiques et Théologiques, Paris, v. 56, n. 3, p. 369-403, juil. 1972.

CONGAR, Y. Les théologiens et l'Église. Paris: Beauchesene, 1980. (Collection Quatre fleuves, 12).

CONGREGAÇÃO PARAA DOUTRINA DA FÉ. Donum Veritatis. Instrução sobre a vocação eclesial do teólogo. AAS, n. 82, p. 1552-1553, 1990. 
COUTINHO, S. R. Uma Igreja em estado de perseguição. Uma década de opressão e resistência. In: SOUZA, N. de; SBARDELOTTI, E. (org.). Puebla: Igreja na América Latina e no Caribe. Opção pelos pobres, libertação e resistência. Petrópolis: Vozes, 2019. p. 82-92.

DORTEL-CLAUDOT, M. Églises locales, Églises universelle. Lion: Châlet, 1973.

DUSSEL, E. De Medellín a Puebla: uma década de sangue e esperança. De Medellín a Sucre, 1968-1972. São Paulo: Loyola, 1983. 3 v.

EQUIPO DE REFLEXIÓN TEOLÓGICO-PASTORAL. Reflexiones sobre Puebla. Bogotá: Centro de Publicaciones del CELAM, 1980.

FRANCO, R. Teología y magisterio: dos modelos de relación. Estudios Eclesiásticos, Madrid, n. 59, p. 3-25, 1984.

GONZÁLEZ FAUS, J. I. El meollo de la involución eclesial. Razón y Fe, Madrid, v. 220, n. 1089-1090, p. 67-84, 1989.

GUTIÉRREZ, G. A atualidade de Medellín. In: PADIN, Dom Cândido; GUTIÉRREZ, Gustavo; CATÃO, Francisco. Conclusões da Conferência de Medellín - 1968. Trinta anos depois, Medellín ainda é atual? São Paulo: Paulinas, 2010. 273-252.

GUTIÉRREZ, G. La recepción del Vaticano II en América Latina. In: ALBERIGO, G.; JOSSUA, J.-P. (ed.). La recepción del Vaticano II. Madrid: Cristiandad, 1987. p. 213237.

HOUTART, F. Le conseil épiscopal d'Amérique latine accentue son changement. ICI, Paris, n. 481, p. 10-24, 1975.

KELLER, M. A. A Conferência de Puebla: contexto, preparação, realização, conclusões, recepção. In: BRIGHENTI, A.; PASSOS, J. D. (org.). Compêndio das conferências dos bispos da América Latina e Caribe. São Paulo: Paulinas: Paulus, 2017. p. 83-93.

KELLER, M. A. El proceso evangelizador de la Iglesia en América Latina. De Río a Santo Domingo. Medellín, Bogotá, n. 81, p. 5-43, 1995.

KELLER, M. A. Evangelización y liberación: el desafío de Puebla. Madrid: Biblia y Fe, 1987.

KELLER, M. A. Puebla y la década de los ochenta en la pastoral de la Iglesia Latinoamericana. Medellín, Bogotá, n. 71, p. 508-521, 1992.

LADRIÈRE, P.; LUNEAU, R. (dir.). Le retour des certitudes: événements et orthodoxie depuis Vatican II. Paris: Le Centurion, 1987.

LIBANIO, J. Batista. Volta à grande disciplina. São Paulo: Loyola, 1984.

LORSCHEIDER, Aloísio. Observações a respeito da Instrução sobre Alguns Aspectos da Teologia da Libertação. Revista Eclesiástica Brasileira, Petrópolis, n. 176, p. 700-708, 1984 . 
MARINS, José et al. De Medellín a Puebla: a práxis dos padres na América Latina. São Paulo: Paulinas, 1979.

MCGRATH, M. G. El mensaje vivo de Puebla. Bogotá: Centro de Publicaciones del CELAM, 1981.

MESTERS, Carlos. O Projeto "Palavra-Vida” e a leitura fiel da Bíblia de acordo com a tradição e o magistério da Igreja. Revista Eclesiástica Brasileira, Petrópolis, n. 49, p. 661-673, 1989.

NERY, I. J. Teólogos e pastoralistas: atores dentro e fora das Conferências. In: BRIGHENTI, A.; PASSOS, J. D. (org.). Compêndio das conferências dos bispos da América Latina e Caribe. São Paulo: Paulinas: Paulus, 2017. p. 399-411.

OLIVEROS, Roberto. Historia de la Teología de la Liberación. In: ELLACURÍA, Ignacio; SOBRINO, Jon. Mysterium liberationis: conceptos fundamentales de la Teología de la Liberación. Madrid: Editorial Trotta, 1990.

PALÁCIO, C. Trinta anos de teologia na América Latina. Um depoimento. In: SUSIN, Luís Carlos (org.). O mar se abriu: trinta anos de teologia na América Latina. São Paulo: Soter-Loyola: 2000. p. 51-64.

PASSOS, J. D. Avanços e retrocessos de uma ousadia que continua fazendo caminho. In: BRIGHENTI, A.; PASSOS, J. D. (org.). Compêndio das conferências dos bispos da América Latina e Caribe. São Paulo: Paulinas: Paulus, 2017. p. 159-173.

PASSOS, J. D. O contexto histórico-social de Puebla. In: SOUZA, N. de; SBARDELOTTI, E. (org.). Puebla: Igreja na América Latina e no Caribe. Opção pelos pobres, libertação e resistência. Petrópolis: Vozes, 2019. p. 156-169.

RICHARD, P. (org.). La Iglesia latinoamericana de Medellín a Puebla. Bogotá: CODECAL: CEHILA, 1979.

SCATENA, S. De Medellín a Aparecida, exercício de colegialidade na América Latina. In: SOUZA, N. de; SBARDELOTTI, E. (org.). Puebla: Igreja na América Latina e no Caribe. Opção pelos pobres, libertação e resistência. Petrópolis: Vozes, 2019. p. 51-68.

SCATENA, S. In populo pauperum: la chiesa latino-americana dal Concilio a Medellín (1962-1968). Bolonha: Società Editrice il Mulino, 2008.

SOBRINO, J. El Vaticano II y la Iglesia latinoamericana. In: FLORISTÁN, C.; TAMAYO, J.J. (ed.). El Vaticano II, veinte años después. Madrid: Cristiandad, 1985. p. 105-134.

SOUZA, N. de. Puebla, antecedentes e evento. In: SOUZA, N. de; SBARDELOTTI, E. (org.). Puebla: Igreja na América Latina e no Caribe. Opção pelos pobres, libertação e resistência. Petrópolis: Vozes, 2019. p. 69-81.

TAMAYO ACOSTA, Juan José. Teologías del sur: el giro descolonizador. Madrid: Editorial Trotta, 2017. 